J. Dairy Sci. 99:6627-6638

http://dx.doi.org/10.3168/jds.2015-10446

(C) American Dairy Science Association ${ }^{\circledR}, 2016$.

\title{
Concentrate diet modulation of ruminal genes involved in cell proliferation and apoptosis is related to combined effects of short-chain fatty acid and $\mathrm{pH}$ in rumen of goats
}

\author{
Hongbing Gui and Zanming Shen ${ }^{1}$ \\ Laboratory of Animal Physiology and Biochemistry, Nanjing Agriculture University, Nanjing, China, 210095
}

\begin{abstract}
Short-chain fatty acids (SCFA) regulate cell proliferation and cell apoptosis in gastrointestinal tissue in vitro and in vivo. We have tested the hypothesis that a medium-concentrate intake induces mRNA abundance alterations of genes involved in cell proliferation and cell apoptosis in the rumen epithelium of goats, and that these changes in mRNA abundance are related to ruminal SCFA concentration and ruminal $\mathrm{pH}$. Goats $(\mathrm{n}=16)$ were randomly allocated to 2 groups and fed either a low-concentrate (LC) diet ( $10 \%$ concentrate; n $=8)$ or a medium-concentrate (MC) diet (35\% concentrate; $\mathrm{n}=8$ ) in 2 equal portions daily. The individually housed goats were fed separately with their respective diet for $3 \mathrm{wk}$ and were slaughtered $6 \mathrm{~h}$ after the morning feed on $\mathrm{d} 22$. In vivo, goats receiving the MC treatment exhibited a greater ruminal SCFA concentration $(73.7 \mathrm{mM})$ compared with those receiving the LC treatment $(53.2 \mathrm{mM})$, and the $\mathrm{pH}$ decreased from 6.9 to 6.5. The expression of proliferative genes of cyclin A, cyclin B1, cyclin D1, cyclin E1, CDK1, CDK2, CDK4, and $C D K 6$ mRNA in the MC group was enhanced. The gene expression of apoptosis genes (caspase 3, caspase 8, caspase 9, p53, and Bax) was significantly higher, and the ratio of $B c l-2$ to $B a x(B c l-2 / B a x)$ expression was lower in the MC group than in the LC group. The same trend was observed in the population of apoptotic cells analyzed by terminal deoxynucleotidyl transferasemediated dUTP nick-end labeling assay. The cell density in the stratum germinativum of the MC group was significantly increased compared with that in the LC group. During primary culture of rumen epithelial cells, SCFA or $\mathrm{pH}$ treatment alone of the culture medium had significant effects on the expression of most of the genes tested in the present study. Furthermore, SCFA
\end{abstract}

Received September 25, 2015 .

Accepted March 28, 2016.

${ }^{1}$ Corresponding author: zmshen@njau.edu.cn and $\mathrm{pH}$ exerted combined effects on the expression of cyclin A, cyclin B1, cyclin E1, CDK6, p53, Bcl-2, and $B c l-2 / B a x$. Thus, the MC diet induces alteration of gene expression of the genes that regulate both cell proliferation and apoptosis. These genes are regulated by combined effect of ruminal SCFA and ruminal $\mathrm{pH}$. Key words: rumen epithelium, gene expression, cell proliferation, cell apoptosis, short-chain fatty acid and $\mathrm{pH}$

\section{INTRODUCTION}

Short-chain fatty acids (SCFA) are produced in the rumen through the microbial fermentation of food and are absorbed by the rumen papillae (Rémond et al., 1996). The rumen absorbs the energy substances [i.e., SCFA, which make approximately $70 \%$ of the energy requirement for growth, maintenance, and production in ruminants (Bergman, 1990)]. The diet influences the rumen papillae surface area and thus the rumen absorptive capacity (Gäbel et al., 1987; Bannink et al., 2008) and animal health. As ruminal fermentation products, SCFA induce morpho-functional alterations in ruminal papillae (Gäbel et al., 1991a; Krehbiel et al., 1992; Nozière et al., 2000); conversely, an increase of SCFA absorption in ruminants fed high-concentrate diets has been linked to a surface area enlargement of ruminal papillae (Dirksen et al., 1984; Gäbel et al., 1991a,b). The latter might be attributable to an increased abundance of gene transcripts related to epithelial proliferation (Penner et al., 2011).

The rumen epithelium is continually exposed to luminal SCFA. The concentration of ruminal SCFA is affected by feed intake. The changes of luminal SCFA are negatively related to changes in acidity. Accumulating study has proved that SCFA in the gut affect mucosal homeostasis (Neish, 2009; Plöger et al., 2012), epithelial absorption (Malhi et al., 2013), and gene expression (Macfarlane and Macfarlane, 2011; Yan et al., 2014). The SCFA and acidic $\mathrm{pH}$ also affect the growth and function of rumen epithelial cells (Steele et al., 2011; Plöger et al., 2012; Yang et al., 2012). 
Cell proliferation and cell apoptosis are 2 important processes of cell life. Mucous membrane cells are constantly in a dynamic balance between proliferation and apoptosis. Cell proliferation and cell apoptosis must be synchronously coordinated to maintain mucosal integrity and its normal function. The majority of previous studies have been conducted on animals or tissues, such as rat and human intestinal and colonic epithelium (Ichikawa and Sakata, 1998; Ichikawa et al., 2002; Blottière et al., 2003), with only a few studies using goat rumen epithelium (Lu et al., 2013; Zhao et al., 2014). To date, little is known about the molecular basis of epithelial proliferation and apoptosis in the rumen epithelial cells of the goat. The combined effect of SCFA and $\mathrm{pH}$ on the cell cycle in these rumen epithelial cells are not yet understood.

We have hypothesized that the feeding of a mediumconcentrate diet would affect the expression of genes involved in cell growth, including those related to cell proliferation and cell apoptosis, and that dietary effects on the expression of genes are associated with ruminal SCFA and $\mathrm{pH}$. Our current experiments have therefore focused on the effects of diet [low-concentrate (LC; $10 \%$ concentrate) vs. medium-concentrate (MC; $35 \%$ concentrate)] on cell proliferation and apoptosis in the ruminal epithelium of the goat and have investigated the combined effect of SCFA concentration and $\mathrm{pH}$ acidity on expression of genes related to cell proliferation and cell apoptosis in goat rumen epithelial cells in primary culture.

\section{MATERIALS AND METHODS}

The experimental design and procedures were approved by the Animal Care and Use Committee of Nanjing Agricultural University, following the requirements of the Regulations for the Administration of Affairs Concerning Experimental Animals (The State Science and Technology Commission of P. R. China, 1988).

\section{Experimental Design and Goat Management}

Sixteen goats $(14.5 \pm 1.1 \mathrm{~kg}$ of BW, Boer $\times$ Yangtze River Delta White), 4 mo of age at the commencement of the experiment, were used for the feeding trial. The treatments contained concentrate at $10 \%$ (low-concentrate, LC) and $35 \%$ (medium-concentrate, MC) of dietary DM. The composition of the MC and LC diets is presented in Table 1. Replacing part (almost 30\%) of guinea grass with corn meal increased the dietary NFC concentration from 14.7 to $31.3 \%$ and decreased the dietary NDF concentration by almost $17 \%$. Goats were placed in individual pens $(1.2 \times 1.0 \mathrm{~m})$ with free access to water and were fed in 2 equal portions at 0800
Table 1. Composition of diets and DMI for low-concentrate (LC) and medium-concentrate $(\mathrm{MC})$ treatments

\begin{tabular}{|c|c|c|}
\hline \multirow[b]{2}{*}{ Item } & \multicolumn{2}{|c|}{ Treatment } \\
\hline & $\mathrm{LC}$ & $\mathrm{MC}$ \\
\hline \multicolumn{3}{|l|}{ Ingredient ( $\%$ of $\mathrm{DM})$} \\
\hline Guinea grass & 90 & 65 \\
\hline Corn meal & 0 & 25 \\
\hline Soybean meal & 8 & 8 \\
\hline Mineral and vitamin supplement ${ }^{1}$ & 1 & 1 \\
\hline Salt & 0.25 & 0.25 \\
\hline $\mathrm{CaHPO}_{4}$ & 0.75 & 0.75 \\
\hline \multicolumn{3}{|l|}{ Chemical composition } \\
\hline $\mathrm{DM}(\%)$ & 91.4 & 89.9 \\
\hline $\mathrm{CP}(\%$ of $\mathrm{DM})$ & 10.3 & 10.7 \\
\hline Crude fat (\% of DM) & 3.5 & 3.4 \\
\hline Ash $(\%$ of DM) & 4.7 & 3.9 \\
\hline $\mathrm{NDF}(\%$ of $\mathrm{DM})$ & 66.8 & 50.7 \\
\hline $\mathrm{NFC}^{2}(\%$ of $\mathrm{DM})$ & 14.7 & 31.3 \\
\hline ME (MJ/kg of DM) & 8.9 & 10.1 \\
\hline \multicolumn{3}{|l|}{ Intake } \\
\hline Guinea grass $(\mathrm{g} / \mathrm{d})$ & $421.7 \pm 10.8$ & $321.2 \pm 7.0$ \\
\hline Corn meal $(\mathrm{g} / \mathrm{d})$ & 0 & 168 \\
\hline Soybean meal $(\mathrm{g} / \mathrm{d})$ & 53.6 & 53.6 \\
\hline $\mathrm{N}\left[\mathrm{mg} /\left(\mathrm{kg}^{0.75} \cdot \mathrm{d}\right)\right]$ & $916.0 \pm 20.2$ & $961.8 \pm 13.0$ \\
\hline $\mathrm{ME}\left[\mathrm{kJ} /\left(\mathrm{kg}^{0.75} \cdot \mathrm{d}\right)\right]$ & $543.8 \pm 12.4$ & $630.1 \pm 8.3^{*}$ \\
\hline \multicolumn{3}{|l|}{ BW of the goats $(\mathrm{kg})$} \\
\hline Beginning of trial & $14.4 \pm 1.2$ & $14.6 \pm 1.5$ \\
\hline End of trial & $14.9 \pm 1.1$ & $15.4 \pm 1.4$ \\
\hline
\end{tabular}

${ }^{1}$ Contained $16 \%$ calcium carbonate, $102 \mathrm{~g} / \mathrm{kg}$ of $\mathrm{Zn}, 47 \mathrm{~g} / \mathrm{kg}$ of $\mathrm{Mn}$, $26 \mathrm{~g} / \mathrm{kg}$ of $\mathrm{Cu}, 1,140 \mathrm{mg} / \mathrm{kg}$ of I, $500 \mathrm{mg} / \mathrm{kg}$ of Se, $340 \mathrm{mg} / \mathrm{kg}$ of Co, $17,167,380 \mathrm{IU} / \mathrm{kg}$ of vitamin A, $858,370 \mathrm{IU} / \mathrm{kg}$ of vitamin $\mathrm{D}$, and $23,605 \mathrm{IU} / \mathrm{kg}$ of vitamin $\mathrm{E}$.

${ }^{2} \mathrm{NFC}=100-(\mathrm{NDF}+\mathrm{CP}+$ crude fat + ash $)$.

*Different from LC $(P<0.05)$.

and $1700 \mathrm{~h}$ daily. The amounts of feed offered and refused by each goat were recorded daily throughout the experiment. The amount of feed supplied was adjusted to ensure approximately $25 \%$ orts. Adaptation to the diets was carried out over $10 \mathrm{~d}$, and goats received their respective treatment for at least $21 \mathrm{~d}$ before slaughter. All goats were slaughtered, $6 \mathrm{~h}$ after the morning feed, at a local slaughterhouse. The goats for experiments were stunned by captive bolt and killed by exsanguination.

Feed was sampled at d 7 and 21 for chemical analysis. The samples of the feed refusals were collected for DM determination on the same day. The DM, ash, CP, and crude fat contents were determined as in our previous work (Malhi et al., 2013). The concentration of NDF was determined by using amylase and sodium sulfite (Van Soest et al., 1991).

\section{Sample Collection}

Immediately after slaughter, subsamples of ruminal fluid were collected in equal portions from the atrium ruminis, ventral rumen, caudal dorsal, and caudal ven- 
tral regions separately and then combined to form 1 sample. The ruminal fluid $(30 \mathrm{~mL})$ was strained through 3 layers of cheesecloth and immediately subjected to $\mathrm{pH}$ measurement. Thereafter, $5 \% \mathrm{HgCl}_{2}$ solution (1.5 $\mathrm{mL}$ ) was added, and the sample was stored at $-20^{\circ} \mathrm{C}$. Rumen tissue from the ventral blind sac was quickly excised, cleaned of loosely adherent feed particles, placed in ice-cold PBS (pH 7.4), and repeatedly rinsed until the PBS remained clear. Ruminal tissues (about $2 \mathrm{~cm}^{2}$ ) for the morphometric analyses and terminal deoxynucleotidyl transferase-mediated dUTP nick-end labeling (TUNEL) assay were fixed in $4 \%$ paraformaldehyde solution. Epithelium for the cell cycle analysis and cell culture was transported in ice-cold PBS to the laboratory. Epithelium for extraction of RNA was separated from the muscle layers and transferred into liquid $\mathrm{N}_{2}$ within 5 min and stored at $-80^{\circ} \mathrm{C}$.

\section{Morphometric and Histomorphometric Analyses}

Tissue samples from the ventral sac ruminis of 8 goats in each group were used to evaluate the histomorphology. Samples were fixed in $4 \%$ paraformaldehyde overnight, dehydrated, cleared, and embedded in paraffin. Sections of 5 to $7 \mu \mathrm{m}$ in thickness were cut and stained by the standard hematoxylin and eosin procedure. The ruminal tissue selected for histomorphological analysis contained papillae with almost identical shape and size. For each tissue, 25 to 30 papillae were embedded for paraffin-sectioning and microscopic observation. From these, the 4 paraffin sections with the best orientation of papillae in the median sagittal plane were used to evaluate the morphological characteristics of the ruminal papillae by using Image-Pro Plus 6.0 (Media Cybernetics Inc., Bethesda, MD).

The number of cell layers forming the stratum corneum (SC) and stratum germinativum (SGv) was counted. Epithelial cell density (number $/ \mathrm{mm}^{2}$ ) was measured in SGv and in the stratum basale (SB).

\section{Cell Culture}

Rumen epithelial cells were isolated from the rumen epithelium of 8 healthy goats (Boer $\times$ Yangtze River Delta White, aged 6-12 mo; both sexes) with $0.25 \%$ trypsin (Sunshine Chemical Co. Ltd., Nanjing, China) as described previously (Lu et al., 2015). Immediately after death, the epithelium from the ventral blind sac of each goat was quickly excised, and these tissues were placed in ice-cold PBS ( $\mathrm{pH}$ 7.4). The tissues were repeatedly rinsed until the PBS remained clear. The muscle layers were then removed, and the epithelium was repeatedly digested with $0.25 \%$ trypsin in D-Hanks' buffered salt solution with antibiotics un- til individual epithelial cells appeared in the digestion solution. Cells were washed with culture medium. For each cell culture, we prepared several cell culture flasks. The viability of the cells was confirmed by staining with trypan blue, and the cell density was adjusted to $1,000,000$ cells $/ \mathrm{mL}$ in high-glucose $(4,500 \mathrm{mg} / \mathrm{L})$ Dulbecco's modified Eagle's medium (Life Technologies Inc., Gibco/Brl Division, Grand Island, NY) with $10 \%$ fetal bovine serum (Zhejiang Tianhang Biological Technology Co. Ltd., Hangzhou, China), $2 \mathrm{~m} M$ L-glutamine (Sunshine Chemical Co. Ltd., Nanjing, China), 100 U/ $\mathrm{mL}$ of penicillin, and $100 \mathrm{mg} / \mathrm{mL}$ of streptomycin. The cells were seeded in $25-\mathrm{cm}^{2}$ plastic tissue culture flasks (Corning Inc., Corning, NY) and incubated at $37^{\circ} \mathrm{C}$ in an incubator $\left(5 \% \mathrm{CO}_{2}\right)$ for $24 \mathrm{~h}$. Thereafter, the cells were allocated across treatments in the following manner: at $\mathrm{pH} 7.4$ (control; $\mathrm{n}=8)$ or $6.8(\mathrm{n}=8)$ for $24 \mathrm{~h}$ or in $20 \mathrm{~m} M$ SCFA at $\mathrm{pH} 7.4(\mathrm{n}=8)$ or $6.8(\mathrm{n}=8)$ for $24 \mathrm{~h}$. Subsequently, the cells were scraped off the flasks and transferred to $-80^{\circ} \mathrm{C}$ until analysis for gene expression. The mixture of SCFA contained $12 \mathrm{~m} M$ sodium acetate, $5 \mathrm{~m} M$ sodium propionate, and $3 \mathrm{~m} M$ sodium butyrate (Merck KGaA, Darmstadt, Germany). In the pH 6.8 group, the medium was acidified with $1 \mathrm{~N} \mathrm{HCl}$.

\section{pH and SCFA Determination}

The $\mathrm{pH}$ of rumen fluid was measured with a Mettler Toledo Delta $320 \mathrm{pH}$ meter (Mettler-Toledo Group, Halstead, UK). An Agilent gas chromatograph HP6890N (GC HP6890N, Agilent Technologies Inc., New Castle, DE) was used to measure SCFA concentrations, as described before (Lu et al., 2015). The GC was equipped with a flame ionization detector and a $30 \mathrm{~m} \times$ $0.32 \mathrm{~mm}$ internal diameter $\times 0.25 \mathrm{~m}$ film thickness HPFFAP capillary column (Hewlett-Packard, Palo Alto, CA). The carrier gas was $\mathrm{N}_{2}(99.99 \%$ purity) and had a constant flow rate of $2.8 \mathrm{~mL} / \mathrm{min}$ and a split ratio of $1: 30$. The temperature of the capillary column was set to $140^{\circ} \mathrm{C}$ for $4 \mathrm{~min}$ and then was raised by $25^{\circ} \mathrm{C} /$ min to $240^{\circ} \mathrm{C}$. The temperatures of the injection port and the flame ionization detector were 180 and $250^{\circ} \mathrm{C}$, respectively.

\section{Cell Isolation and Flow Cytometry Assay}

Cells were isolated from rumen epithelial tissue (10 $\mathrm{g}$ of wet weight, sampled from the ventral blind sac ruminis) by using $0.25 \%$ trypsin. This method was described previously ( $\mathrm{Lu}$ et al., 2015). Immediately after death, the epithelium from the ventral blind sac of each goat was quickly excised, and these tissues were placed in ice-cold PBS ( $\mathrm{pH}$ 7.4). The tissues were repeatedly rinsed until the PBS remained clear. The muscle layers 
were then removed, and the epithelium was repeatedly digested with $0.25 \%$ trypsin in D-Hanks' buffered salt solution with antibiotics until individual epithelial cells appeared in the digestion solution. Cells were washed with culture medium. Isolated cells were fixed in ethanol $(75 \%)$, washed, and treated with RNase solution $\left(100 \mathrm{U} / \mathrm{mL}\right.$ in $\left.\mathrm{PBS}, 37^{\circ} \mathrm{C}, 30 \mathrm{~min}\right)$, followed by incubation with propidium iodide (70 $\mathrm{m} M$ in PBS) for $30 \mathrm{~min}$ and analysis on a BD FACScan Flow Cytometer (BD Biosciences, San Jose, CA). The cell cycle was analyzed by a computer-aided Multicycle Program (Phoenix, San Diego, CA).

\section{TUNEL Assay}

The TUNEL detection of DNA fragmentation was carried out by using a TUNEL BrightRed Apoptosis Detection Kit (Vazyme, Apoptosis Detection Kit) according to the manufacturer's instructions. The cells were then observed and photographed by a Laser Scanning Confocal Microscope (Zeiss LSM700, Carl Zeiss, Jena, Germany) at 460 and $620 \mathrm{~nm}$. The apoptotic index was obtained from the ratio between apoptotic and normal nuclei multiplied by 100 (Bozzo et al., 2014).

\section{RNA Extraction and Real-Time Quantitative PCR}

Total RNA extraction was carried out as previously described (Yang et al., 2012). The RNA concentration was then quantified by measuring the absorbance at $260 \mathrm{~nm}$ with a Biophotometer (Eppendorf, Hamburg, Germany). The absorption ratio $(260 / 280 \mathrm{~nm})$ of all samples was between 1.8 and 2.0. Aliquots of RNA samples were subjected to electrophoresis through a $1.4 \%$ agarose-formaldehyde gel to verify integrity. Complementary DNA was synthesized by using a random hexamer primer (Invitrogen, Shanghai, China) and M-MLV-reverse transcriptase according to the manufacturer's instructions (MBI Fermentas Inc., Burlington, ON, Canada). The primers for cyclin D1, $C D K_{4}$, caspase 3, caspase $8, B c l-2$, and $B a x$ were used as described (Deng et al., 2005; Shimizu et al., 2010; Dessauge et al., 2011; Malhi et al., 2013). The primers for the other genes were designed by Primer Premier 5.0 software (Premier Biosoft International, Palo Alto, CA). The PCR products of the newly designed primers were validated by DNA sequencing. The target genes of interest and their respective sources and primer sequences are listed in Table 2. The primers were all synthesized by Shanghai Invitrogen Biological Co. (Shanghai, China).

Determination of relative gene expression was performed with real-time quantitative PCR by using the MyiQ2 2-color real-time quantitative PCR detection system (Bio-Rad Laboratories Inc., Hercules, CA). Real-time PCR was carried out in a total volume of 20 $\mu \mathrm{L}$ containing $1 \times \mathrm{iQ}$ SYBR Green Supermix (Bio-Rad Laboratories Inc.), a mixture of forward and reverse primers (500 nM each), cDNA template (1 ng), and sterile water for volume adjustment. An initial cycle for $30 \mathrm{~s}$ at $95^{\circ} \mathrm{C}$ was used to denature the cDNA. This was followed with 45 PCR cycles consisting of denaturation at $95^{\circ} \mathrm{C}$ for $5 \mathrm{~s}$ and primer annealing and extension at $60^{\circ} \mathrm{C}$ for $30 \mathrm{~s}$. After all PCR analyses, a melting curve analysis was carried out. All investigated PCR products exhibited only a single melting peak. Before the performance of PCR for experimental samples, the amplification efficiencies of all primers were calculated by using a standard dilution series. The efficiencies of all the primers used were between 97 and 101\%. All samples were analyzed in triplicate. These experiments were repeated twice with 80 to $90 \%$ similarity. Gene expression was normalized to that of $G A P D H(\triangle \mathrm{Ct}=$ $\mathrm{Ct}_{\text {target }}-\mathrm{Ct}_{\text {GAPDH }}$, where $\mathrm{Ct}=$ cycle threshold). The average $\Delta \mathrm{CT}$ value of the control group (LC group in vivo experiment and $\mathrm{pH} 7.4$ group in vitro experiment) was then used as a reference value to calculate $\Delta \Delta \mathrm{Ct}$. The relative expression values were calculated by using the following formula: relative expression $=2^{-\Delta \Delta \mathrm{Ct}}$ (Livak and Schmittgen, 2001).

\section{Statistical Analyses}

Data are expressed as the means \pm standard error. Differences with a $P$-value of $<0.05$ were considered significant. Data involving more than 2 groups were assessed by a one-way ANOVA and Student-NewmanKeuls' post hoc analysis after testing for homogeneity of variance. An independent $t$-test (2-tailed test) was used to compare data between 2 groups. The general linear model with relevant interactions was used to determine the significance of the effects of SCFA and $\mathrm{pH}$ in vitro. All statistical analyses were performed by using SPSS software (version 13.0.1 for Windows, SPSS, Chicago, IL).

\section{RESULTS}

\section{Ruminal Fermentation}

The goats in the MC group had a lower ruminal $\mathrm{pH}$ than goats in the LC group (6.5 vs. $6.9, P<0.05$, Table $3)$. In agreement with the ruminal $\mathrm{pH}$ results, the total ruminal SCFA was higher in the MC group compared with the LC group. Of all 6 SCFA analyzed, feeding with $\mathrm{MC}$ increased $(P<0.05)$ the concentration of propionate by $75 \%$, butyrate by $85 \%$, isobutyrate $40 \%$, valerate by $85 \%$, and isovalerate by $67 \%$. 
Table 2. Primers for real-time PCR

\begin{tabular}{|c|c|c|c|}
\hline Gene $^{1}$ & Primer sequence $\left(5^{\prime} \text { to } 3^{\prime} \text {; forward, reverse }\right)^{2}$ & Source $^{3}$ & $\begin{array}{l}\text { Size } \\
(\mathrm{bp})\end{array}$ \\
\hline$G A P D H$ & $\begin{array}{l}\text { TTGTCTCCTGCGACTTCA } \\
\text { CCACCACCCTGTTACTGTT }\end{array}$ & HМ043737.1 & 135 \\
\hline$C C N A$ & $\begin{array}{l}\text { TGGACCTTCACCAGACCTACCT } \\
\text { GTGGGTTGAGGAGAGAAACACC }\end{array}$ & X68321.1 & 105 \\
\hline$C C N B 1$ & $\begin{array}{l}\text { AGCGGATCCAAACCTTTGTAGTG } \\
\text { CAATGAGGATGGCTCTCATGTTTC }\end{array}$ & NM_001045872.1 & 137 \\
\hline$C C N D 1$ & $\begin{array}{l}\text { GGTCCTGGTGAACAAACTC } \\
\text { TTGCGGATGATCTGCTT }\end{array}$ & Malhi et al., 2013 & 114 \\
\hline CCNE1 & $\begin{array}{l}\text { GGGACAAGCACCTTATGCAAC } \\
\text { GTGTTGCCATATACCGATCAAAGA }\end{array}$ & NM_001192776.1 & 153 \\
\hline$C D K 1$ & $\begin{array}{l}\text { CCAATAATGAAGTGTGGCCAGAAG } \\
\text { AGAAATTCGTTTGGCAGGATCATAG }\end{array}$ & NM_174016.2 & 164 \\
\hline$C D K 2$ & $\begin{array}{l}\text { CTGCACCGAGACCTTAAACCTCA } \\
\text { GCTCGGTACCACAGAGTCACCA }\end{array}$ & ВТ020790.1 & 140 \\
\hline$C D K_{4}$ & $\begin{array}{l}\text { TGAGCATCCCAATGTTGT } \\
\text { CCTTGTCCAGATACGTCCT }\end{array}$ & Malhi et al., 2013 & 122 \\
\hline$C D K 6$ & $\begin{array}{l}\text { AGAGTGATTGCAGCTTTATGTCCA } \\
\text { TGCCCAGGTTGCTCACTTC } \\
\text { AGATGAGGTAAAGCCCGTCA }\end{array}$ & GAAI01006376.1 & 158 \\
\hline Caspase 3 & $\begin{array}{l}\text { AGCCATGGTGAAGAAGGAATCA } \\
\text { ACCACAGTCCAGTTCTGTGCCT }\end{array}$ & Dessauge et al., 2011 & 156 \\
\hline Caspase 8 & $\begin{array}{l}\text { TGCCTACAGGATTCTGCTTT } \\
\text { CCAGCTTACATTTGGCAATC }\end{array}$ & Deng et al., 2005 & 104 \\
\hline Caspase 9 & $\begin{array}{l}\text { TCCTTTGTTCATCTCCTGCTTG } \\
\text { TTTTCCTTGGCTTGGCTTTG }\end{array}$ & XM_004013798.1 & 115 \\
\hline p53 & $\begin{array}{l}\text { CCCATCCTCACCATCATCAC } \\
\text { GCACAAACACGCACCTCAA }\end{array}$ & X81704.1 & 80 \\
\hline Bcl-2 & $\begin{array}{l}\text { GATGACCGAGTATCTGAACCG } \\
\text { GACAGCCAGGAGAAATCAAACA }\end{array}$ & Shimizu et al., 2010 & 120 \\
\hline Bax & $\begin{array}{l}\text { TCTGACGGCAACTTCAACTG } \\
\text { TGGGTGTCCCAAAGTAGGAG }\end{array}$ & Shimizu et al., 2010 & 205 \\
\hline \multicolumn{4}{|c|}{$\begin{array}{l}{ }^{1} C C N A=\text { cyclin } \mathrm{A} ; C C N B 1=\text { cyclin } \mathrm{B} 1 ; C C N D 1=\text { cyclin } \mathrm{D} 1 ; C C N E 1=\text { cyclin } \mathrm{E} 1 ; C D K 1=\text { cyclin-dependent } \\
\text { kinase } 1 ; C D K 2=\text { cyclin-dependent kinase } 2 ; C D K 4=\text { cyclin-dependent kinase } 4 ; C D K 6=\text { cyclin-dependent } \\
\text { kinase } 6 ; B c l-2=\mathrm{B} \text {-cell lymphoma } 2 ; B a x=\mathrm{Bcl}-2 \text {-associated } \mathrm{X} \text { protein. } \\
{ }^{2} \text { The first primer listed for each gene is the forward primer, and the second primer is the reverse primer. } \\
{ }^{3} \text { The reference sequence number is given for primers whose source is the National Center for Biotechnology } \\
\text { Information (NCBI) GenBank database (http://www.ncbi.nlm.nih.gov/genbank/). }\end{array}$} \\
\hline
\end{tabular}

\section{Papillae Morphology and Rumen Epithelial Growth}

The cell densities in $\mathrm{SGv}(P<0.05)$ in the ruminal ventral sac were higher in the MC group than in the LC

Table 3. Effect of feeding low concentrate (LC) or medium concentrate (MC) diets on ruminal short-chain fatty acid (SCFA) and $\mathrm{pH}$ in goats $6 \mathrm{~h}$ after feeding ${ }^{1}$

\begin{tabular}{lrrr}
\hline & \multicolumn{2}{c}{ Treatment } & \\
\cline { 2 - 3 } Item & \multicolumn{1}{c}{ LC } & \multicolumn{1}{c}{$\mathrm{MC}$} & $P$-value \\
\hline $\mathrm{pH}$ & $6.9 \pm 0.07$ & $6.5 \pm 0.12$ & 0.03 \\
Acetate $(\mathrm{m} M)$ & $33.0 \pm 1.31$ & $42.0 \pm 2.24$ & 0.08 \\
Propionate $(\mathrm{m} M)$ & $11.4 \pm 0.40$ & $20.0 \pm 0.93$ & 0.01 \\
Butyrate $(\mathrm{m} M)$ & $4.8 \pm 0.81$ & $8.9 \pm 0.69$ & 0.04 \\
Isobutarate $(\mathrm{m} M)$ & $1.0 \pm 0.04$ & $1.4 \pm 0.14$ & 0.04 \\
Valerate $(\mathrm{m} M)$ & $1.0 \pm 0.01$ & $1.4 \pm 0.05$ & $<0.01$ \\
Isovalerate $(\mathrm{m} M)$ & $1.2 \pm 0.04$ & $2.0 \pm 0.24$ & 0.02 \\
Total SCFA $(\mathrm{m} M)$ & $53.2 \pm 2.10$ & $73.7 \pm 0.84$ & 0.01 \\
\hline
\end{tabular}

${ }^{1}$ Goats $(\mathrm{n}=8)$ received the LC or MC diet at least $21 \mathrm{~d}$ before slaughter. Values are means \pm standard error. group, and the number of cell layers tended to increase $(P=0.08)$. However, the numbers of cell layers in SC and the cell densities in SB were not different between the LC and MC groups (Table 4).

\section{Analyses of Cell Cycle}

Dietary MC affected the cell cycle progression (Table $5)$. The cell number percentage was lower in the $\mathrm{G}_{0} /$ $\mathrm{G}_{1}$ phase $(79.6$ vs. $86.4 \%, P<0.05)$ but higher in the $\mathrm{S}$ phase $(5.5$ vs. $4.2 \%, P<0.05)$ and the $\mathrm{G}_{2} / \mathrm{M}$ phase $(15.0$ vs. $9.5 \%, P<0.05)$ in the $\mathrm{MC}$ group compared with those in the LC group.

\section{Analyses of TUNEL Assay}

The apoptotic index (Figure 1) was significantly $(P$ $<0.001$ ) different between the MC and LC groups. Supplemental Figure S1 (http://dx.doi.org/10.3168/ jds.2015-10446) shows that the TUNEL-positive cells 
Table 4. Effect of feeding low concentrate (LC) or medium concentrate (MC) diets on ruminal histometric characteristics in ruminal epithelium of goats $6 \mathrm{~h}$ after feeding ${ }^{1}$

\begin{tabular}{lccc}
\hline & \multicolumn{2}{c}{ Treatment } & \\
\cline { 2 - 3 } Item & LC & MC & $P$-value \\
\hline Thickness of epithelial strata (number of cell layers) & $3.4 \pm 0.14$ & $3.7 \pm 0.11$ & 0.08 \\
$\quad$ Stratum germinativum & $2.4 \pm 0.14$ & $2.5 \pm 0.12$ & 0.27 \\
Stratum corneum & & & \\
Cell density in epithelial strata & $6,850.3 \pm 135.13$ & $7,268.3 \pm 73.23$ & 0.02 \\
Stratum germinativum (no./ $\mathrm{mm}^{2}$ ) & $266.3 \pm 9.33$ & $275.2 \pm 8.43$ & 0.42 \\
Stratum basale (no./mm) & & & \\
\hline
\end{tabular}

${ }^{1}$ Goats $(\mathrm{n}=8)$ received the LC or MC diet at least $21 \mathrm{~d}$ before slaughter. Rumen papillae samples for histomorphometry were collected from the ruminal ventral sac of 8 goats of each group. Values are means \pm standard error.

are mostly found at the superficial aspects of the ruminal epithelium, including the SC and stratum granulosum (SG), by using the TUNEL assay. The goats in the MC group had higher apoptotic indices than goats in the LC group (6.3 vs. $2.0 \% ; P<0.001)$.

\section{Gene Expression In Vivo in Goats Fed by MC or LC Diet}

The expression of genes related to cell-cycle-regulating proteins (Figure 2; e.g., cyclin A, cyclin B1, cyclin D1, cyclin E1, CDK1,CDK2,CDK4, and $C D K 6$ ) was upregulated in the MC group compared with that in the LC group. The expression of the genes that regulate cell apoptosis (Figure 3), namely caspase 3, caspase 8, caspase 9, p53, Bcl-2, and Bax, was also evaluated by real-time quantitative PCR. Their relative expression in the MC group was enhanced compared with that in the LC group, with the exception of $B c l-2$, which was decreased. The ratio of $B c l-2$ to $B a x(B c l-2 / B a x)$ was also reduced $(P<0.01)$ in the $\mathrm{MC}$ group.

Table 5. Effect of feeding low concentrate (LC) or medium concentrate (MC) diets on cell cycle progression in ruminal epithelium of goats 6 $\mathrm{h}$ after feeding ${ }^{1}$

\begin{tabular}{lrrr}
\hline & \multicolumn{2}{c}{ Treatment } & \\
\cline { 2 - 3 } Item $^{2}$ & \multicolumn{1}{c}{$\mathrm{LC}$} & \multicolumn{1}{c}{$\mathrm{MC}$} & $P$-value \\
\hline $\mathrm{G}_{0} / \mathrm{G}_{1}(\%)$ & $86.4 \pm 1.64$ & $79.6 \pm 0.44$ & 0.02 \\
$\mathrm{~S}(\%)$ & $4.2 \pm 0.32$ & $5.5 \pm 0.16$ & 0.02 \\
$\mathrm{G}_{2} / \mathrm{M}(\%)$ & $9.5 \pm 1.33$ & $15.0 \pm 0.30$ & 0.02 \\
\hline
\end{tabular}

${ }^{1}$ Goats $(\mathrm{n}=8)$ received the LC or MC diet at least $21 \mathrm{~d}$ before slaughter. Samples from 8 goats of each group were used for flow-cytometric analysis. Values are means \pm standard error.

${ }^{2} \mathrm{G}_{0} / \mathrm{G}_{1}=$ the proportion of cells in the gap $\mathrm{G}_{0}$ phase and $\mathrm{G}_{1}$ phase (the percentage is based on 10,000 cells); $\mathrm{S}=$ the proportion of cells in the synthesis (S) phase, based on the fact that the single-cell DNA level is higher than the DNA content of resting diploid cells (the percentage is based on 10,000 cells measured); $\mathrm{G}_{2} / \mathrm{M}=$ the proportion of mitotic cells (the percentage is based on 10,000 cells).

\section{Gene Expression in Primary Culture of Rumen Epithelial Cells}

A decrease of $\mathrm{pH}$ from 7.4 to 6.8 in the culture medium increased $(P<0.05)$ cyclin D1, CDK2, and $C D K 6$ gene expression by 80,113 , and $189 \%$ after $24 \mathrm{~h}$ of primary cell culture (Figure 4). At pH 7.4, the presence of SCFA $(20 \mathrm{mM})$ in the culture medium led to an increase of $(P<0.05)$ cyclin $\mathrm{A}$, cyclin $\mathrm{D} 1$, cyclin $\mathrm{E} 1$, $C D K 2, C D K 4$, and $C D K 6$ gene expression by 51, 107, $201,68,123$, and $59 \%$, respectively, as compared with the absence of SCFA in the medium. Moreover, the combined application of both low $\mathrm{pH}$ and SCFA ( $\mathrm{pH}$ $6.8+$ SCFA $20 \mathrm{mM}$ ) to the culture medium resulted in upregulated $(P<0.05)$ gene expression of cyclin B1, cyclin E1, CDK1, and CDK4 by $119,790,53$, and $79 \%$, respectively, compared with the culture medium at $\mathrm{pH} 6.8$, but no added SCFA. In the culture medium

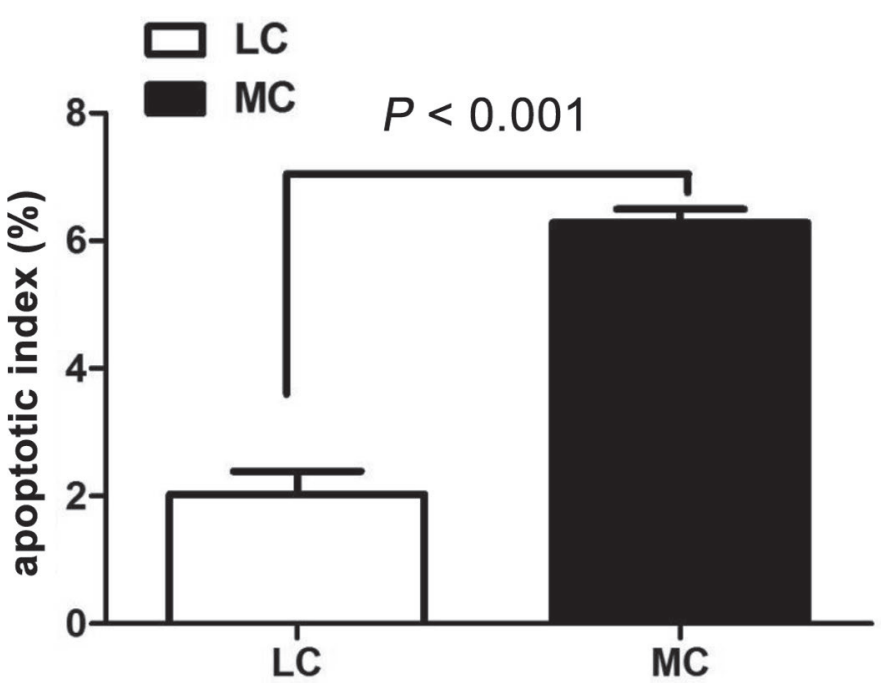

Figure 1. Effect of feeding low concentrate (LC) or medium concentrate (MC) diets on the cell apoptotic index in the ruminal epithelium of goats. Goats received the LC or MC diet for $21 \mathrm{~d}$. Values are mean \pm SEM, $\mathrm{n}=8$ 


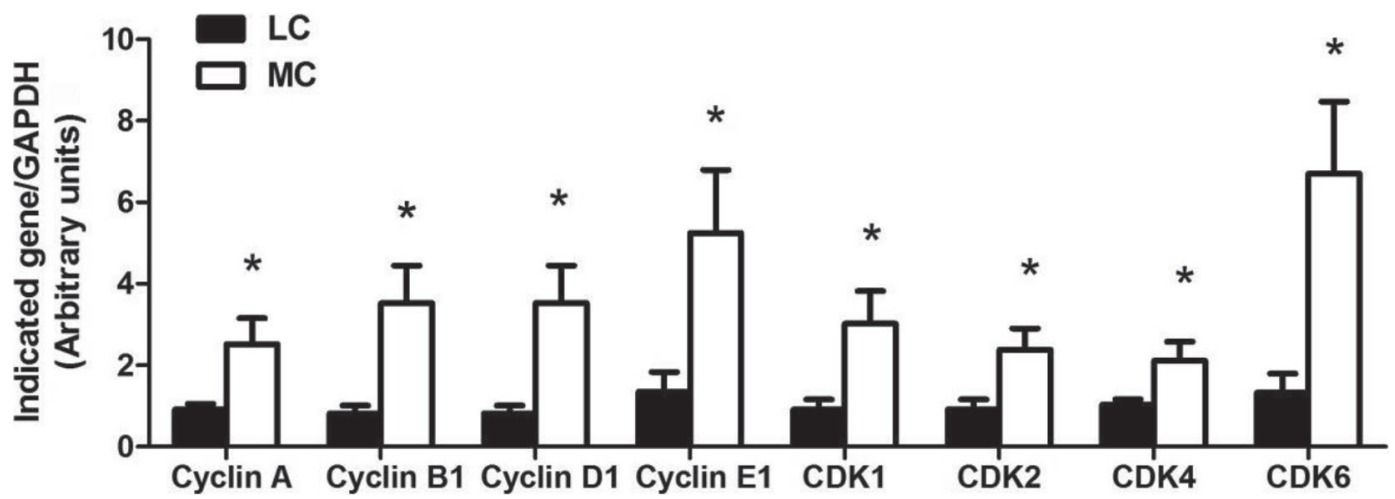

Figure 2. Effect of feeding low concentrate (LC) or medium concentrate (MC) diets on the expression of genes related to cell cycle regulators in the ruminal epithelium of goats. Goats received the $\mathrm{LC}$ or $\mathrm{MC}$ diet for $21 \mathrm{~d}$. Values are mean $\pm \mathrm{SEM}, \mathrm{n}=8 .{ }^{*}$ indicates different from LC $(0.01<P<0.05)$.

with SCFA $(20 \mathrm{mM})$, a decrease of $\mathrm{pH}$ from 7.4 to 6.8 resulted in the upregulation $(P<0.05)$ of gene expression of cyclin B1, cyclin E1, CDK1, CDK2, and CDK6 by $94,153,47,45$, and $23 \%$, respectively. However, it led to a reduction of the gene expression of cyclin A $(P$ $<0.05)$.

A combination of SCFA and $\mathrm{pH}$ exerted synergistic effects on the expression of cyclin A, cyclin B1, cyclin E1, and CDK6 (interaction: $P<0.05$ ). The SCFA or $\mathrm{pH}$ treatment alone of the culture medium exhibited similar effects as they did in the combined treatment in the present study.

The expression of genes that regulate cell apoptosis; for example, caspase 3 , caspase 8 , caspase $9, p 53, B c l$ 2, and Bax, was also evaluated by real-time quantitative PCR in primary cell culture after $24 \mathrm{~h}$ of culture (Figure 5). In the culture medium at $\mathrm{pH} 6.8$, the gene expression of caspase 3 , caspase 8 , caspase 9 , and $p 53$ increased significantly $(P<0.05)$ by $221,95,93$, and
$61 \%$ compared with that at $\mathrm{pH}$ 7.4. Conversely, the ratio of Bcl-2 to Bax (Bcl-2/Bax) was downregulated ( $P$ $<0.05)$. At $\mathrm{pH} 7.4$, the presence of SCFA $(20 \mathrm{mM})$ in the medium increased $(P<0.05)$ caspase 3 , caspase 9 , and Bax gene expression by 84,101 , and $126 \%$, respectively, as compared with the medium with no SCFA, whereas the gene expression of caspase $8, p 53$, and the ratio of $B c l-2$ to $B a x(B c l-2 / B a x)$ was decreased $(P<$ $0.05)$ under this culture condition. Moreover, a combined application of both low $\mathrm{pH}$ and SCFA $(\mathrm{pH} 6.8+$ SCFA $20 \mathrm{mM}$ ) in the medium resulted in an increase $(P<0.05)$ in the gene expression of caspase 3, Bcl-2, and $B a x$ by 30,126 , and $35 \%$ compared with that in medium at $\mathrm{pH} 6.8$ but no SCFA. However, the gene expression of caspase 8 and $p 53$ was reduced $(P<0.05)$. A further comparison between the effects of $\mathrm{pH} 7.4+$ SCFA $(20 \mathrm{mM})$ and $\mathrm{pH} 6.8+\mathrm{SCFA}(20 \mathrm{mM})$ showed that medium at $\mathrm{pH} 6.8+\mathrm{SCFA}(20 \mathrm{mM})$ upregulated $(P<0.05)$ the gene expression of caspase 3 by $126 \%$.

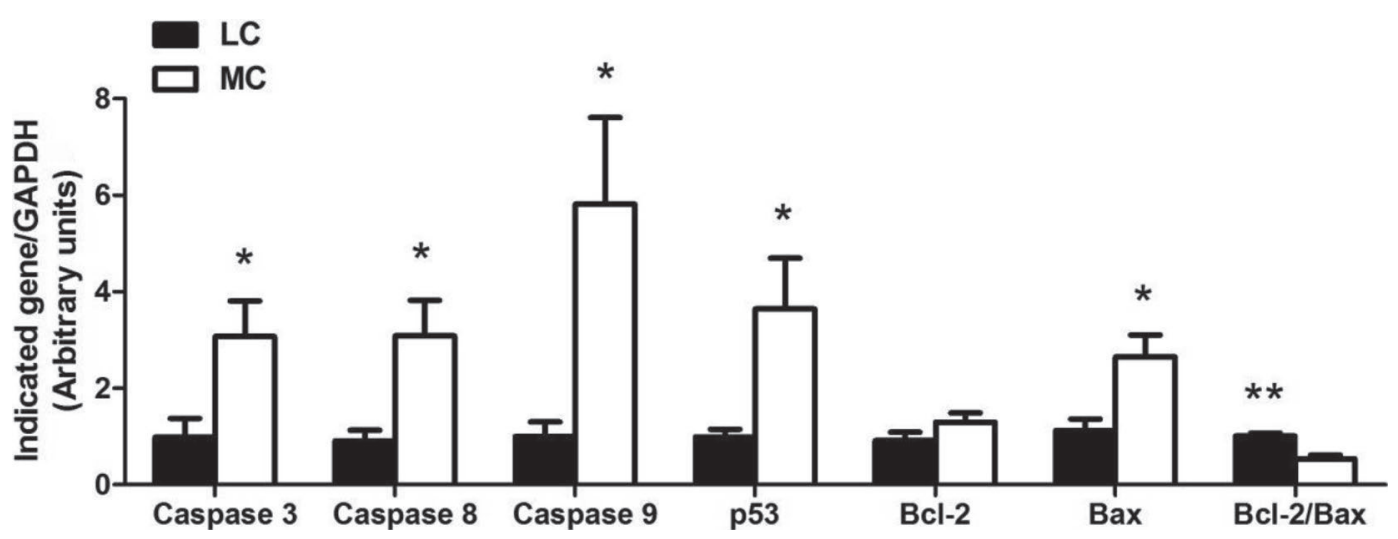

Figure 3. Effect of feeding low concentrate (LC) or medium concentrate (MC) diets on the expression of genes related to cell apoptosis in ruminal epithelium of goats. Goats received the LC or MC diet for $21 \mathrm{~d}$. Values are mean $\pm \mathrm{SEM}, \mathrm{n}=8 .{ }^{*}$ indicates different from LC $(0.01<$ $P<0.05)$. ** indicates different from LC $(P<0.01)$. 


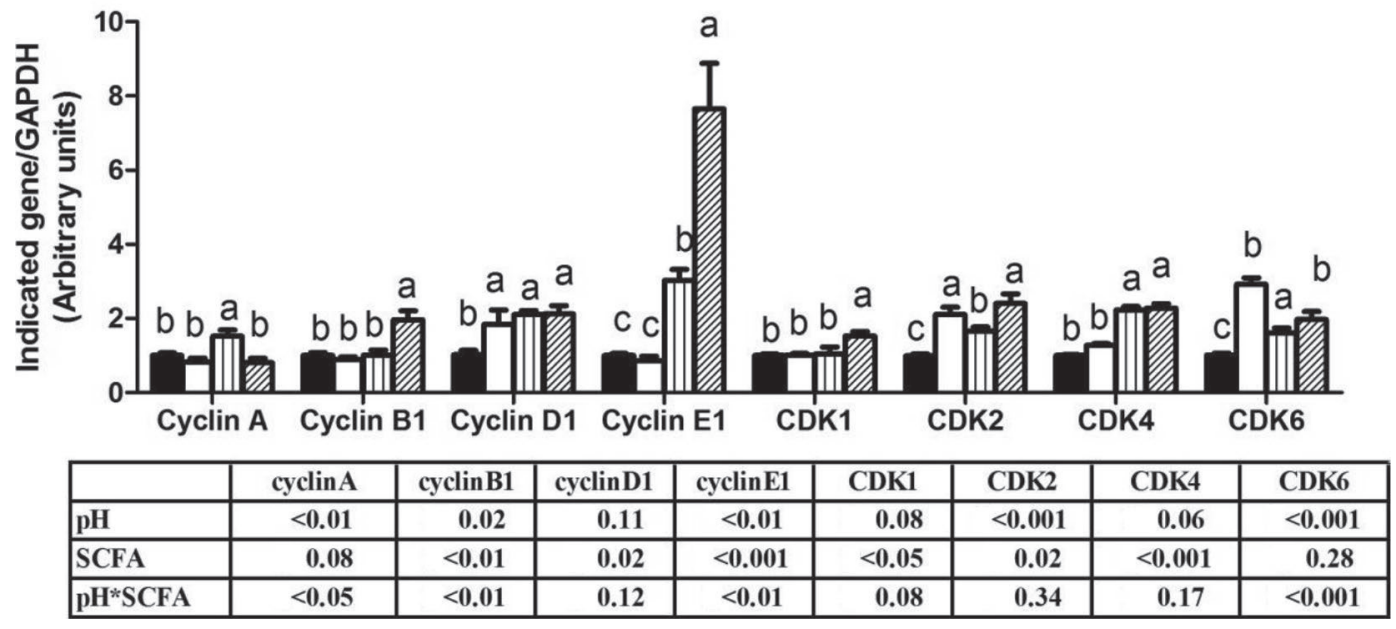

Figure 4. In vitro effects of acid ( $\mathrm{pH} \mathrm{6.8),} \mathrm{short-chain} \mathrm{fatty} \mathrm{acids} \mathrm{(SCFA;} 20 \mathrm{mM}$ ), or acid (pH 6.8) + SCFA (20 mM) on gene expression of cell cycle regulators in rumen epithelial cells of goats after cells were incubated for $24 \mathrm{~h}$. In groups with pH 6.8 treatment, the medium was acidified by $1 \mathrm{~N} \mathrm{HCl}$. The $20 \mathrm{~m} M$ SCFA contained (in $\mathrm{m} M$ ) 12 sodium acetate, 5 sodium propionate, and 3 sodium butyrate. The levels of gene expression were quantified with real-time PCR in comparison with GAPDH. Values are means $\pm \mathrm{SEM}, \mathrm{n}=8$. Values within a group without a common letter $(\mathrm{a}-\mathrm{c})$ are significantly different $(P<0.05)$.
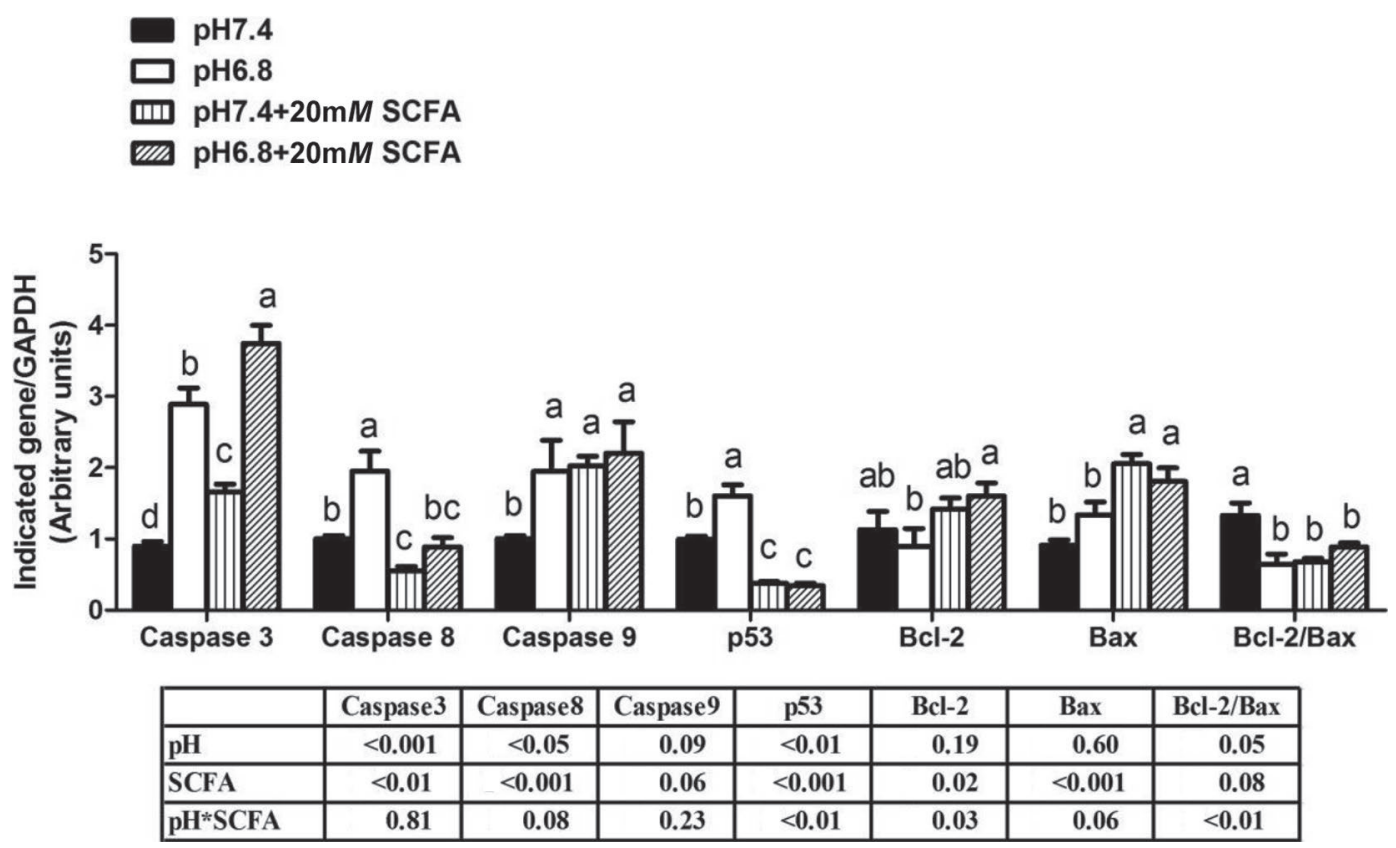

Figure 5. In vitro effects of acid ( $\mathrm{pH}$ 6.8), short-chain fatty acids (SCFA; $20 \mathrm{~m} M$ ), or acid (pH 6.8) + SCFA (20 m $M$ ) on expression of genes associated with cell apoptosis in rumen epithelial cells of goats after cells were incubated for $24 \mathrm{~h}$. In groups with the pH 6.8 treatment, the medium was acidified by $1 \mathrm{~N} \mathrm{HCl}$. The $20 \mathrm{~m} M$ SCFA contained (in $\mathrm{m} M$ ) 12 sodium acetate, 5 sodium propionate, and 3 sodium butyrate. The levels of gene expression were quantified with real-time PCR in comparison with GAPDH. Values are means \pm SEM, $\mathrm{n}=8$. Values within a group without a common letter $(\mathrm{a}-\mathrm{d})$ are significantly different $(P<0.05)$. 
The SCFA or $\mathrm{pH}$ treatment alone of the culture medium exhibited significant effects on the expression of most of the genes tested in the present study. Furthermore, we found that SCFA and $\mathrm{pH}$ exerted synergistic effects on the expression of $p 53, B c l-2$, and Bcl-2/Bax (interaction: $P<0.05$ ).

\section{DISCUSSION}

\section{Ruminal Fermentation}

In the present study, diets varying in percentage of concentrate induce changes in ruminal fermentation. By increasing the proportion of the diet comprised of concentrate from 10 to $35 \%$, we increased SCFA and decreased $\mathrm{pH}$. This result is in agreement with previous reports that have suggested that ruminal $\mathrm{pH}$ decreases and total SCFA concentrations increase as the dietary concentrate to forage ratio (Yan et al., 2014), high-grain diet (Liu et al., 2013; Metzler-Zebeli et al., 2013; Mao et al., 2016), or the NFC level (Lu et al., 2015) increases. In present study, the 2 diets tested had equally energy-providing and nitrogen contents. They were in the maintenance level. However, the NFC in the MC group was higher than that in the LC group to cause a decrease in ruminal $\mathrm{pH}$ and an increase in total SCFA concentration. Our aim was to investigate the effect of SCFA and $\mathrm{pH}$ on ruminal cell proliferation and apoptosis.

\section{Effects of Diet on Ruminal Cell Cycle and Expression of Related Genes}

Cellular proliferation is controlled primarily by the regulation of the cell cycle, which consists of 4 distinct but sequential phases $\left(G_{1}, S, G_{2}\right.$, and $M$ phase $)$. The $\mathrm{G}_{1}$ phase is the phase of cell growth. The $\mathrm{S}$ phase is the phase of DNA replication. The $\mathrm{G}_{2}$ phase distributes to the duplication of chromosomes, and the $\mathrm{M}_{2}$ is the cell division phase. In addition to $\mathrm{G}_{1}, \mathrm{~S}, \mathrm{G}_{2}$, and $\mathrm{M}$ phases, the term $\mathrm{G}_{0}$ is used to describe cells that have exited the cell cycle and become quiescent (Norbury and Nurse, 1992). In this study, the proportion of cells in the $G_{0} / G_{1}$ phase was lower, whereas that in the Sphase and $G_{2} / M$ phases was higher in the $M C$ group, indicating that the time duration of the $\mathrm{G}_{1}$ phase was shortened and the cell cycle progression was accelerated under the MC treatment.

The cell cycle control system is based on 2 protein families: the cyclin-dependent protein kinases (CDK) and the cyclins (Vermeulen et al., 2003). The $2 \mathrm{G}_{1}$ cyclins are cyclin D1 and cyclin E. The binding of cyclin D1 to CDK4 and to CDK6 to form complexes is essential for entry in $\mathrm{G}_{1}$ phase (Mathew et al., 2010).
The cyclin E, which binds to CDK2, promotes progression from $\mathrm{G}_{1}$ into $\mathrm{S}$ phase (Ohtsubo et al., 1995). The complex of cyclin A and CDK2 is required in S phase (Girard et al., 1991; Walker and Maller, 1991). The cyclin A and CDK1 complex promotes cells entry into $\mathrm{M}$ phase. This progression is further regulated by cyclin B in complex with CDK1 (King et al., 1994; Arellano and Moreno, 1997). Any change in the duration of one or more phases of the cell cycle will affect the rate of cell production (Shen et al., 2004). In present experiments, the gene expression of the cell cycle regulators (cyclin $\mathrm{A}$, cyclin $\mathrm{B} 1$, cyclin $\mathrm{D} 1$, cyclin $\mathrm{E} 1, C D K 1, C D K 2$, $C D K_{4}$, and $C D K 6$ ) was enhanced in goats in the $\mathrm{MC}$ group compared with the LC group, indicating these cell cycle regulators promoting cell cycle progression in the MC group. These data lead to the speculation that the cell cycle of the rumen was promoted when goats were fed the MC diet, a finding that is consistent with the result of the cell cycle. In the present study, the ruminal SCFA increases and $\mathrm{pH}$ decreases in growing goats by increasing the proportion of the dietary concentrate from 10 to $35 \%$. This is in agreement with previous reports (Yang et al., 2012; Yan et al., 2014). It has been shown that concentrate feeding caused an increase of rumen papillae number and enlargement of papillae size. This is associated with accelerated epithelial proliferation (Shen et al., 2004; Lu et al., 2013). The effect of concentrate feeding on rumen papillae growth is partly related to luminal factors such as rumen-generated SCFA (mainly butyric acid) and pH (Gäbel et al., 1987; Uppal et al., 2003). The higher concentration of SCFA was considered as the promoter of the rumen epithelial cell proliferation (Ørskov, 1976). McLeod et al. (2007) further reported that luminal SCFA are the primary stimuli for proliferation.

\section{Effects of Diet on Ruminal Cell Apoptosis and Expression of Related Genes}

In the present experiments, we successfully used the staining and detection of TUNEL-positive cells in ruminal epithelium, with TUNEL-positive cells being most numerous at the lumen side of the ruminal epithelium. The mucosal surface of goat rumen is covered by stratified squamous epithelium, which is composed of 4 cell layers the SC, SG, stratum spinosum, and SB. The apoptotic cells usually occur in SC and SG. This result is in agreement with previous reports that the TUNELpositive cells are most prevalent toward the base of the gastric glands in the stomach epithelium (Hall et al., 1994). The apoptotic index of rumen epithelial cells is higher in the MC group than in the LC group. This was supported by the gene expression study. 
In the present experiments, the gene expression of the cell apoptosis regulators (caspase 3 , caspase 8 , caspase $9, p 53$, and $B a x$ ) was all enhanced in goats in the MC group, compared with the LC group, and the ratio of Bcl-2 to Bax (Bcl-2/Bax) was reduced. These data lead to the speculation that cell apoptosis in the rumen is promoted when goats are fed the MC diet, as is consistent with the result of the TUNEL experiments. In brief, the intake of a $35 \%$ concentrate diet leads to both an accelerated ruminal cell cycle and the promotion of ruminal cell apoptosis. At the maintenance level, the nutritive material arising from apoptotic cell can used for cell proliferation, which might be conducive to epithelial homeostasis.

\section{Papillae Morphology and Rumen Epithelial Growth}

We have shown that the cell densities in SGv in the ruminal ventral sac are higher in the $\mathrm{MC}$ group than in the LC group. In accordance with our results, previous studies have shown that an increase of SCFA absorption in ruminants fed high-concentrate diets is linked to the surface area enlargement of ruminal papillae (Dirksen et al., 1984; Gäbel et al., 1991a). The latter might be attributable to an increased abundance of gene transcripts related to epithelial proliferation (Penner et al., 2011). However, the cell densities in SGv of the MC group is only increased $6.1 \%$ compared with the LC group, and the number of cell layers in $\mathrm{SC}$ and the cell densities in SB were not different between the LC and MC groups. We speculate that, in this experiment, not only an increase of cell proliferation, but also an increase in cell death occurs in the ruminal epithelium. In conclusion, the $35 \%$ concentrate diet (with a normal grain level) can promote cell proliferation of the ruminal papillae.

\section{In Vitro Combined Effects of SCFA and pH}

Multicellular organisms have many potent physiological mechanisms that govern cell proliferation and tissue homeostasis. Most of the growth-control mechanisms are connected to apoptosis. Apoptosis can be induced in the case of inappropriate growth, for example, excess proliferation or growth in these cells (Schmitz et al., 2000). During the last century and more recently, a surge of studies was carried out to determine the effect of SCFA on ruminal epithelium cell proliferation (Sakata and Yajima, 1984; Neogrády et al., 1989; Malhi et al., 2013); however, most of those studies examined cell proliferation and not cell apoptosis and did not further investigate the influencing factors. Nevertheless, previous studies have shown that luminal factors, especially
SCFA and $\mathrm{pH}$, can act as modulators of gene transcription ( $\mathrm{Li}$ and Li, 2006; Lu et al., 2015; Yan et al., 2014). Furthermore, we have observed marked differences in ruminal fermentation measurements, including SCFA concentration and ruminal $\mathrm{pH}$ in the vivo experiment. Based on the above information, we have assumed that SCFA and $\mathrm{pH}$ affect the transcription of genes related to cell cycle regulators and cell apoptosis. To test this assumption, we have conducted in vitro trials.

Our primary cell culture experiments have shown that SCFA and an acidic pH both upregulate proliferation and increase senescence, sloughing, or both. These results are in accord with previous studies that have shown that SCFA, such as acetic, propionic, and nbutyric acids, stimulate the epithelial cell proliferation of the large intestine in rats (Sakata, 1987; Kripke et al., 1989) and human colonic mucosa (Scheppach et al., 1992). The SCFA, especially butyrate, stimulate cell apoptosis (Kurita-Ochiai et al., 1997; McMillan et al., 2003) in certain types of cells (murine thymocytes, splenic T cells, human Jurkat T cells, and human colon adenoma cells). The present study has indicated that epithelial gene and protein expression in the rumen is mainly affected by luminal factors that act via the apical cell membrane (Sanderson and Naik, 2000). The SCFA, which generated from microbial fermentation, can regulate host gene expression via the cell cycle and apoptosis. The study of the interactions between gut microbiota and host represents an active field of research (den Besten et al., 2013). By using the general linear model with relevant interactions, we have found that the genes cyclin A, cyclin B1, cyclin E1, CDK6, p53, Bcl-2, and Bcl-2/Bax are regulated by the combined effects of SCFA and $\mathrm{pH}$.

For tissue cell homeostasis, the balance between cell gain via mitosis and cell loss by differentiation and apoptosis is critical. In consequence, enhanced proliferation might be a compensatory response to replace the cells lost by necrosis or apoptosis. This is partly related to luminal factors such as rumen-generated SCFA (mainly butyric acid) and $\mathrm{pH}$ in the rumen epithelium. Thus, SCFA and $\mathrm{pH}$ are physiological modulators of cell number in the rumen epithelium and can regulate rumen epithelium homeostasis not only by proliferation, but also by apoptosis. The above results have shown that an $\mathrm{MC}$ diet has a crucial role in maintaining rumen epithelial homeostasis and integrity, which is beneficial to animal health. The SCFA and proton interact with their receptors to adapt the change of energy density of the diet. The interaction of SCFA and proton with their receptors affect ruminal epithelial growth and physical structure. The further research has the potential to increase our understanding of absorptive area plasticity under changing dietary conditions. 


\section{CONCLUSIONS}

An increase of dietary concentrate from 10 to $35 \%$ causes both an accelerated ruminal cell cycle and promotes ruminal cell apoptosis. In parallel, the expression of genes related to regulators of the cell cycle (cyclin A, cyclin B1, cyclin D1, cyclin E1, CDK1,CDK2,CDK4, and $C D K 6$ ) and of cell apoptosis (caspase 3, caspase 8, caspase $9, p 53$, and $B a x$ ) is enhanced depending upon the percentage of the dietary concentrate. In primary cell culture, SCFA and acidic $\mathrm{pH}$ modulate ruminal genes involved in cell proliferation and apoptosis. Taken together, our data demonstrate that increase of SCFA concentration and decrease of $\mathrm{pH}$ are putative regulators of gene expression in rumen epithelium. This study, therefore, provides new insights into the epithelial homeostasis and molecular adaptation of rumen epithelium to adequate concentrate intake.

\section{ACKNOWLEDGMENTS}

This work was supported by the Key Basic Research Program (973 Program) in China (no. 2011CB100801), the National Natural Science Foundation of China (Beijing, China; no. 30771568), and the Priority Academic Program Development of Jiangsu Higher Education Institutions (PAPD, China).

\section{REFERENCES}

Arellano, M., and S. Moreno. 1997. Regulation of CDK/cyclin complexes during the cell cycle. Int. J. Biochem. Cell Biol. 29:559-573.

Bannink, A., J. France, S. Lopez, W. Gerrits, E. Kebreab, S. Tamminga, and J. Dijkstra. 2008. Modelling the implications of feeding strategy on rumen fermentation and functioning of the rumen wall. Anim. Feed Sci. Technol. 143:3-26.

Bergman, E. 1990. Energy contributions of volatile fatty acids from the gastrointestinal tract in various species. Physiol. Rev. 70:567-590.

Blottière, H. M., B. Buecher, J.-P. Galmiche, and C. Cherbut. 2003. Molecular analysis of the effect of short-chain fatty acids on intestinal cell proliferation. Proc. Nutr. Soc. 62:101-106.

Bozzo, A., C. Soñez, I. Monedero Cobeta, A. Rolando, M. Romanini, D. Cots, M. Lazarte, H. Gauna, and M. Mugnaini. 2014. Chronic stress and its effects on adrenal cortex apoptosis in pregnant rats. Biotech. Histochem. 89:296-303.

den Besten, G., K. van Eunen, A. K. Groen, K. Venema, D.-J. Reijngoud, and B. M. Bakker. 2013. The role of short-chain fatty acids in the interplay between diet, gut microbiota, and host energy metabolism. J. Lipid Res. 54:2325-2340.

Deng, M., J. Liu, C. N. Pelak, C. A. Lancto, and M. S. Abrahamsen. 2005. Regulation of apoptotic pathways in bovine $\gamma / \delta$ T cells. Vet. Immunol. Immunopathol. 105:15-23.

Dessauge, F., V. Lollivier, B. Ponchon, R. Bruckmaier, L. Finot, S. Wiart, E. Cutullic, C. Disenhaus, S. Barbey, and M. Boutinaud. 2011. Effects of nutrient restriction on mammary cell turnover and mammary gland remodeling in lactating dairy cows. J. Dairy Sci. 94:4623-4635.

Dirksen, G., H. Liebich, G. Brosi, H. Hagemeister, and E. Mayer. 1984. Morphology of the rumen mucosa and fatty acid absorption in cattle-important factors for health and production. Zentralbl. Veterinarmed. A 31:414-430.
Gäbel, G., H. Martens, M. Sündermann, and P. Galfi. 1987. The effect of diet, intraruminal $\mathrm{pH}$ and osmolarity on sodium, chloride and magnesium absorption from the temporarily isolated and washed reticulo-rumen of sheep. Q. J. Exp. Physiol. 72:501-511.

Gäbel, G., M. Bestmann, and H. Martens. 1991a. Influences of diet, short-chain fatty acids, lactate and chloride on bicarbonate movement across the reticulo-rumen wall of sheep. J. Vet. Med. A. $38: 523-529$.

Gäbel, G., S. Vogler, and H. Martens. 1991b. Short-chain fatty acids and $\mathrm{CO}^{2}$ as regulators of $\mathrm{Na}^{+}$and $\mathrm{Cl}^{-}$absorption in isolated sheep rumen mucosa. J. Comp. Physiol. B 161:419-426.

Girard, F., U. Strausfeld, A. Fernandez, and N. J. Lamb. 1991. Cyclin A is required for the onset of DNA replication in mammalian fibroblasts. Cell 67:1169-1179.

Hall, P. A., P. J. Coates, B. Ansari, and D. Hopwood. 1994. Regulation of cell number in the mammalian gastrointestinal tract: the importance of apoptosis. J. Cell Sci. 107:3569-3577.

Ichikawa, H., and T. Sakata. 1998. Stimulation of epithelial cell proliferation of isolated distal colon of rats by continuous colonic infusion of ammonia or short-chain fatty acids is nonadditive. J. Nutr. 128:843-847.

Ichikawa, H., R. Shineha, S. Satomi, and T. Sakata. 2002. Gastric or rectal instillation of short-chain fatty acids stimulates epithelial cell proliferation of small and large intestine in rats. Dig. Dis. Sci. 47:1141-1146.

King, R. W., P. K. Jackson, and M. W. Kirschner. 1994. Mitosis in transition. Cell 79:563-571.

Krehbiel, C. R., D. Harmon, and J. Schneider. 1992. Effect of increasing ruminal butyrate on portal and hepatic nutrient flux in steers. J. Anim. Sci. 70:904-914.

Kripke, S. A., A. D. Fox, J. M. Berman, R. G. Settle, and J. L. Rombeau. 1989. Stimulation of intestinal mucosal growth with intracolonic infusion of short-chain fatty acids. JPEN J. Parenter. Enteral Nutr. 13:109-116.

Kurita-Ochiai, T., K. Fukushima, and K. Ochiai. 1997. Butyric acidinduced apoptosis of murine thymocytes, splenic T cells, and human Jurkat T cells. Infect. Immun. 65:35-41.

Li, R. W., and C. Li. 2006. Butyrate induces profound changes in gene expression related to multiple signal pathways in bovine kidney epithelial cells. BMC Genomics 7:234.

Liu, J.-H., T.-T. Xu, Y.-J. Liu, W.-Y. Zhu, and S.-Y. Mao. 2013 A high-grain diet causes massive disruption of ruminal epithelial tight junctions in goats. Am. J. Physiol. Regul. Integr. Comp. Physiol. 305:R232-R241.

Livak, K. J., and T. D. Schmittgen. 2001. Analysis of relative gene expression data using real-time quantitative PCR and the $2^{-\triangle \Delta \mathrm{CT}}$ method. Methods 25:402-408.

Lu, J., H. Zhao, J. Xu, L. Zhang, L. Yan, and Z. Shen. 2013. Elevated cyclin D1 expression is governed by plasma IGF-1 through Ras/ Raf/MEK/ERK pathway in rumen epithelium of goats supplying a high metabolizable energy diet. J. Anim. Physiol. Anim. Nutr. (Berl.) 97:1170-1178.

Lu, Z., H. Gui, L. Yao, L. Yan, H. Martens, J. R. Aschenbach, and Z. Shen. 2015. Short-chain fatty acids and acidic $\mathrm{pH}$ upregulate UTB, GPR41, and GPR4 in rumen epithelial cells of goats. Am. J. Physiol. Regul. Integr. Comp. Physiol. 308:R283-R293.

Macfarlane, G. T., and S. Macfarlane. 2011. Fermentation in the human large intestine: Its physiologic consequences and the potential contribution of prebiotics. J. Clin. Gastroenterol. 45:S120-S127.

Malhi, M., H. Gui, L. Yao, J. R. Aschenbach, G. Gäbel, and Z. Shen. 2013. Increased papillae growth and enhanced short-chain fatty acid absorption in the rumen of goats are associated with transient increases in cyclin D1 expression after ruminal butyrate infusion. J. Dairy Sci. 96:7603-7616.

Mao, S. Y., W. J. Huo, and W. Y. Zhu. 2016. Microbiome-metabolome analysis reveals unhealthy alterations in the composition and metabolism of ruminal microbiota with increasing dietary grain in a goat model. Environ. Microbiol. 18:525-541.

Mathew, O. P., K. Ranganna, and F. M. Yatsu. 2010. Butyrate, an HDAC inhibitor, stimulates interplay between different posttranslational modifications of histone H3 and differently alters G1-spe- 
cific cell cycle proteins in vascular smooth muscle cells. Biomed. Pharmacother. 64:733-740.

McLeod, K. R., R. Baldwin, M. Solomon, and R. Baumann. 2007. Influence of ruminal and postruminal carbohydrate infusion on visceral organ mass and adipose tissue accretion in growing beef steers. J. Anim. Sci. 85:2256-2270.

McMillan, L., S. Butcher, J. Pongracz, and J. Lord. 2003. Opposing effects of butyrate and bile acids on apoptosis of human colon adenoma cells: Differential activation of PKC and MAP kinases. Br. J. Cancer 88:748-753.

Metzler-Zebeli, B. U., M. Hollmann, and S. Sabitzer. 2013. Epithelial response to high-grain diets involves alteration in nutrient transporters and $\mathrm{Na} / \mathrm{K}$-ATPase mRNA expression in rumen and colon of goats. J. Anim. Sci. 91:4256-4266.

Neish, A. S. 2009. Microbes in gastrointestinal health and disease. Gastroenterology 136:65-80.

Neogrády, S., P. Gálfi, F. Kutas, and T. Sakata. 1989. The effects of butyrate and glucagon on the proliferation of ruminal epithelial cells in culture. Vet. Res. Commun. 13:27-29.

Norbury, C., and P. Nurse. 1992. Animal cell cycles and their control. Annu. Rev. Biochem. 61:441-470.

Nozière, P., C. Martin, D. Rémond, N. B. Kristensen, R. Bernard, and M. Doreau. 2000. Effect of composition of ruminally-infused shortchain fatty acids on net fluxes of nutrients across portal-drained viscera in underfed ewes. Br. J. Nutr. 83:521-531.

Ohtsubo, M., A. M. Theodoras, J. Schumacher, J. M. Roberts, and M. Pagano. 1995. Human cyclin E, a nuclear protein essential for the G1-to-S phase transition. Mol. Cell. Biol. 15:2612-2624.

Ørskov, E. 1976. The effect of processing on digestion and utilization of cereals by ruminants. Proc. Nutr. Soc. 35:245-252.

Penner, G., M. Steele, J. Aschenbach, and B. McBride. 2011. Ruminant Nutrition Symposium: Molecular adaptation of ruminal epithelia to highly fermentable diets. J. Anim. Sci. 89:1108-1119.

Plöger, S., F. Stumpff, G. B. Penner, J. D. Schulzke, G. Gäbel, H Martens, Z. Shen, D. Günzel, and J. R. Aschenbach. 2012. Microbial butyrate and its role for barrier function in the gastrointestinal tract. Ann. N. Y. Acad. Sci. 1258:52-59.

Rémond, D., F. Meschy, and R. Boivin. 1996. Metabolites, water and mineral exchanges across the rumen wall: mechanisms and regulation. Proc. Ann. Zootech. 45:97-119.

Sakata, T. 1987. Stimulatory effect of short-chain fatty acids on epithelial cell proliferation in the rat intestine: a possible explanation for trophic effects of fermentable fibre, gut microbes and luminal trophic factors. Br. J. Nutr. 58:95-103.

Sakata, T., and T. Yajima. 1984. Influence of short chain fatty acids on the epithelial cell division of digestive tract. Q. J. Exp. Physiol. 69:639-648.
Sanderson, I., and S. Naik. 2000. Dietary regulation of intestinal gene expression. Annu. Rev. Nutr. 20:311-338.

Scheppach, W., P. Bartram, A. Richter, F. Richter, H. Liepold, G. Dusel, G. Hofstetter, J. Rüthlein, and H. Kasper. 1992. Effect of short-chain fatty acids on the human colonic mucosa in vitro. J. Parenter. Enteral. Nutr. 16:43-48.

Schmitz, I., S. Kirchhoff, and P. H. Krammer. 2000. Regulation of death receptor-mediated apoptosis pathways. Int. J. Biochem. Cell Biol. 32:1123-1136.

Shen, Z., H.-M. Seyfert, B. Löhrke, F. Schneider, R. Zitnan, A. Chudy, S. Kuhla, H. M. Hammon, J. W. Blum, and H. Martens. 2004. An energy-rich diet causes rumen papillae proliferation associated with more IGF type 1 receptors and increased plasma IGF-1 concentrations in young goats. J. Nutr. 134:11-17.

Shimizu, T., S. Krebs, S. Bauersachs, H. Blum, E. Wolf, and A. Miyamoto. 2010. Actions and interactions of progesterone and estrogen on transcriptome profiles of the bovine endometrium. Physiol. Genomics 42A:290-300.

Steele, M. A., G. Vandervoort, O. AlZahal, S. E. Hook, J. C. Matthews, and B. W. McBride. 2011. Rumen epithelial adaptation to high-grain diets involves the coordinated regulation of genes involved in cholesterol homeostasis. Physiol. Genomics 43:308-316.

Uppal, S., K. Wolf, S. Khahra, and H. Martens. 2003. Modulation of $\mathrm{Na}^{+}$transport across isolated rumen epithelium by short-chain fatty acids in hay-and concentrate-fed sheep. J. Anim. Physiol. Anim. Nutr. (Berl.) 87:380-388.

Van Soest, P. J., J. Robertson, and B. Lewis. 1991. Methods for dietary fiber, neutral detergent fiber, and nonstarch polysaccharides in relation to animal nutrition. J. Dairy Sci. 74:3583-3597.

Vermeulen, K., D. R. Van Bockstaele, and Z. N. Berneman. 2003. The cell cycle: A review of regulation, deregulation and therapeutic targets in cancer. Cell Prolif. 36:131-149.

Walker, D. H., and J. L. Maller. 1991. Role for cyclin A in the dependence of mitosis on completion of DMA replication. Nature 354:314-317.

Yan, L., B. Zhang, and Z. Shen. 2014. Dietary modulation of the expression of genes involved in short-chain fatty acid absorption in the rumen epithelium is related to short-chain fatty acid concentration and $\mathrm{pH}$ in the rumen of goats. J. Dairy Sci. 97:5668-5675.

Yang, W., Z. Shen, and H. Martens. 2012. An energy-rich diet enhances expression of $\mathrm{Na}^{+} / \mathrm{H}^{+}$exchanger isoform 1 and 3 messenger RNA in rumen epithelium of goat. J. Anim. Sci. 90:307-317.

Zhao, H., J. Lu, Z. Huang, L. Yan, M. Holger, and Z. Shen. 2014. High concentrate: Forage ratio diet inhibiting omasal epithelium growth is associated with decreased cyclin D1 and CDK4 expression in growing goats. Anim. Sci. J. 85:660-670. 